\title{
Tangled Memories of a Wounded Storyteller: Notes on Bear History and Cultural Memory
}

\section{LES WRIGHT}

Les Wright is a long-time gay activist / scholar, committed to understanding and promoting progressive social change. He is a publisher of the on-line journal Verisimilitude, and is at present Associate Professor of Humanities and English at a small New England college.

\section{Teaching Trauma}

$\mathrm{E}$ very spring term for the past twelve years I have taught a course called "The Literature of Death and Dying" to mostly undergraduate majors in funeral management and bereavement studies programs. I begin the course by fleshing out the following: aspects of the dying process and conceptualizations of death (one's own, that of a family member, friend, or a stranger's); the varieties of trauma, loss, and grief; survivorship; how individuals experience and give meaning to death, whether experienced as imminent or as an abstraction. We then broaden the focus to embrace collective experiences of death and dying, and the course escalates the degree and scale of trauma and loss, visiting case studies drawn from the pandemics of AIDS and the Black Death, twentieth-century warfare, and the Shoah, concluding with sublime meditation on nuclear annihilation.

As the students progress, overcoming culturally conditioned taboos against talking openly and freely, even "irreverently" about death, they soon realize death and dying are often mostly about us as the survivors of others' deaths, as sentient beings contemplating our own mortality, as complex, spiritual, feeling individuals interconnected with others living and dead. Whether framed in terms 
of psychology, philosophy (including religion and spirituality), politics, social activism, or critical analysis and theory, we each, individually and collectively, must engage with creating meaning. Death, given its seeming finality, is an ultimate other we must all confront. However, the legacy of Western thought teaches us that death is the opposite of life, and has, more thoroughly than any other culture elsewhere in time or place, removed the facts of death from everyday life. The result is we confront death and dying as the ultimate trauma.

In his study God is a Trauma, Greg Mogenson asserts, "whatever traumatizes us becomes our parent" (64). ${ }^{1}$ Used as a medical term, "trauma" originally referred to the blow which caused injury. Later, it became associated with the injury, and "not to the state of mind that ensues but to the event that provoked it" (Erikson 184). Sociologist Kai Erikson clarifies contemporary common usage of trauma, emphasizing how people react to a stress or blow (physical or psychological), rather than to the event itself. The traumatic quality we note ensues from the damage experienced. ${ }^{2}$ Most important to Erikson's definition, and to its application here, is his expansion of the concept: " 'trauma' has to be understood as resulting from a constellation of life experiences as well as from a discrete happening, from a persisting condition as well as from an acute event" (185). ${ }^{3}$ Erikson concludes his broadened definition of trauma, by suggesting that

one can speak of traumatized communities as something distinct from assemblies of traumatized persons, sometimes the tissues of community can be damaged in much the same way as the tissues of mind and body, ... but even when that

1 We may follow Mogenson's lead and set aside for present discussion defining or debating "God" - the idea is the dialogue that becomes possible with the emergence of I-Thou duality, whether it be the soul in conversation with an (imagined) divine presence or the psyche's internal dialogue with itself (-which-is-not-itself).

${ }^{2}$ Clinical psychiatrist Judith Lewis Herman (1992) articulates the signs and symptoms of trauma as reactions to violence, including memory repression, an internalized state of terror, emotional disconnection (as well as numbness or hyperarousal), and expands helpfully on the experience of protracted, repeated, and compound traumatic experiences and their effects.

${ }^{3}$ Viktor Frankl, in developing and implementing logotherapy, clearly subscribes to this understanding. His accounts of his personal journey, and of his clinical practice working with fellow Holocaust survivors, are documented in the acclaimed classic, Man's Search for Meaning. 
does not happen, traumatic wounds inflicted on individuals can combine to create a mood, an ethos-a group culture, almost - that is different from (and more than) the sum of the private wounds that make it up. (185)

Erikson's understanding of traumatized communities is particularly important for my considerations here, especially when we further note that the act of recalling certain memories can become a painful and retraumatizing experience in itself. Anthropologist Allen Young offers a medical-scientific perspective on what he terms "phylogenetic memory," whereby the neurological trace of an event of pain (which creates a memory) is recalled or reenacted periodically, to the degree that it becomes "equivalent to what is called an instinct" (254). As he continues,

[p]ain and fear have been normalized, turned into memories with which the individual can now make his way in the world ...-[T]he meaning of memory is turned inside out, and transformed into a recognizably modern phenomenon: an affliction through which pain and fear colonize and degrade the sufferer's life-world. (258)

Or, as gender theorist Judith Butler puts it, the wound of sexual otherness is that we are "condemned to the social death of extranormativity" (in Salih 3).

\section{Tangled Memories}

In what follows, I seek, in part, to account for and delineate parameters of some intersubjectivities of the traumas of social death as male homosexual, social death as (homosexual male) person with AIDS, the death of the (Castro) clone. This essay is then comprised of two projects of bear history: a personal remembering on my part, as well as a cultural project of memorializing, each documenting for the future what came before and after the birth of bear identities. I seek here, through the very act of recalling to memory, not to extract a rational, linear narrative structure out of a complex, multi-layered web of memory, but rather to document the processes of remembering. In my quest to create a forum for all bear voices to be heard and to collect, document, or preserve all comers, I seek to anticipate and disarm the inevitable historical revision involved whenever lived experience is shaped and interpreted for those who were not present. 
In her seminal study Tangled Memories: The Vietnam War, The AIDS Epidemic, and the Politics of Remembering, Marita Sturken wrestles with the relationship between individual and collective memory, the differently selective remembering and forgetting of cultural memory, and how all this informs what becomes recorded as (official) history. Key to her understanding is how dominant, controlling power or culture can strategically "forget" painful or unhelpful events. Sturken observes that cultural memory is "shared outside the avenues of formal historical discourse yet is entangled with cultural products and imbedded with cultural meaning" (3). Memory itself, Sturken observes, is "a narrative rather than a replica of an experience that can be retrieved and relived" (7).

Similarly, in my own work I have wrestled with the social practices implicated in power dynamics, or what Sturken calls "technologies of memory" (10), as these are involved in evaluating the already elusive and fluid cultural memory of bears as a sexual sub-subculture-before they arrive as gay-mainstream cultural history. To create a public memorial requires a complex process of extricating, extrapolating, and even inventing a clarity and a certainty of knowledge, which always come after the facts of the event. Above all, my goal has been to capture as many snapshots of the first moments of this new bear community as possible. Hence, the "tangled memories," which were so essential to the texture of the original scene of trauma, become altered and watered down by the process of being named, organized, and constructed for deployment to an audience. Therefore, while the sometimes disorienting effect the reader may encounter here is intended, the artifact (this article) is also an original experience recreated in a manner approximating its formation.

\section{My Biomythography: Toward a Personal Archive of Feeling}

My "Literature of Death and Dying" course is designed as both an ultimate amusement-park ride for the intellect and an intense, intimate walk with me through the devastated psychic landscape of my life's history. I interweave deeply personal experiences into the fabric of the course of instruction, without ever communicating the private sources explicitly to my students. It is of course unknowable to the students that they are experiencing my "biomythography." This term, of course, is derived from poet, novelist, and lesbian-feminist activist 


\section{0 / Wright}

Audre Lorde (1934-1992), who classified her (slightly fictionalized) autobiography Zami: A New Spelling of My Name as a "biomythography." In this work, she gives voice to the great pain of her life struggle as a poor working-class woman of Afro-Caribbean descent, as a pre-Stonewall-era lesbian, as a wife and mother in a biracial marriage-in short, as an individual living on multiple social margins. Lorde countered the narratives of dominant society with new self-generated narratives, of mythic effort and proportion, as an act of liberation-as a necessary responsibility for survival, her own and that of others like us. Lorde becomes in this process a kind of living repository of the cultural memories of an entire generation. Whereas the "tangled memories" of trauma survivorship were thoroughly investigated first among Holocaust survivors (for example in the work of Viktor Frankl), Lorde infused similar insights into the social deaths that are the effects of race, gender, and sexual power relationships in the United States.

In the process of developing and teaching my course, I acquired valuable insight into my own survivorship. I am a survivor of many more things than one could guess lurk out there in the world: of incest and childhood sexual abuse, of rape, of alcoholism and drug addiction, of homelessness and destitution (twice in one lifetime!), of AIDS-both as a long-term survivor living with the disease since 1981 and of the "Gay Holocaust." What else can one call the annihilation of one's entire world? In the $1980 \mathrm{~s}$, most of my acquaintances came from the fellowship of gay AA. I lost nearly all of my friends, acquaintances, and neighbors to AIDS. I lived in San Francisco's Castro Street District ${ }^{4}$ at the time and witnessed the mass dying off of my neighbors, my neighborhood, my community. Nearly everyone I knew, including friends living in other gay enclaves across the US and Europe, gay activist and gay-scholarly allies, succumbed. By the time Rock Hudson appeared on the cover of Time magazine and AIDS was suddenly news to Middle America, my safe and happy gay ghetto had been reduced to epidemiological and psychic rubble, and I was waiting for the Grim Reaper to ravage me with disease and disfigurement, to rip me from the claws of life.

${ }^{4}$ For further understanding of how I have conceptualized the significance of the Castro District, see Wright (1999). 
Since then I have lived in a parallel-America universe. In the classic trauma-survivor's sense of living in two times-of "now," but also always of "then," in the profoundest moment of trauma-I have become a cultural survivor, orphaned from my cultures of origin, forever a citizen of Susan Sontag's "gray kingdom." $1980 \mathrm{~s}$, I had also acquired an experience of social death, stemming from long-term unemployment and subsistence-level survival (with the help of a few friends), living on General Assistance as I completed my doctoral dissertation, and graduating to "permanent disability" status, thanks to the generosity of the federal government, the Social Security Administration, and a pittance SSI check.

Subsequently, when I found myself back in the workforce and holding down a steady job in suburban Boston in 1993, I jumped at the chance to develop and teach a course on death and dying. I did this as a survival strategy: to put intellectual distance between myself and my life experiences, to begin to digest this sequence of events intellectually and emotionally, and to give shape to and create meaning for what I had lived through. This has become a life project for me, starting with my early interest in creating gay history and gay culture in the 1970s, to pursuing a double professional existence involved in grassroots gay history in San Francisco while studying European high culture at Berkeley, then by attempting to fuse these interests in attempting a dissertation ${ }^{6}$ on the impact of AIDS in shaping gay cultures in the US and Europe, and finally culminating in examining gay bears, a phenomenon in the midst of which I found myself as it sprang up in the psychic ruins of AIDS-devastated gay San Francisco in the 1980s.

I determined to devote myself to chronicling, documenting, and exploring the emergent bear community. Above all, as a journalistic eyewitness, as an anthropological participant observer, as a critical

5 Susan Sontag opens her essay "Illness as Metaphor" with a discussion of citizens of the gray kingdom, a place where people who become sick metaphorically go, in exile from the living world of healthy people. I explored the real-life dimensions of finding myself living in this metaphorically constructed parallel universe in an unpublished essay I composed in 1989, in which I described what it was like to be living in San Francisco as a person with ARC at the height of the AIDS crisis.

6 The dissertation, as envisioned ideally, has proven to be a lifelong project, and one which has been evolving with the "vicissitudes" of time. An early study for it appeared in article format (see Wright 1992). 
analytical member of this incipient community, as a grassroots-based oral historian, I eagerly embraced the challenge. I had become deeply disaffected-another item to add to my psychic trauma list-by the dramatic recasting of the (radical) gay liberation movement of the early 1970s into the (assimilationist) gay rights movement of the 1980s. As my generation's hippies transformed into 1980s yuppies, so too my gay-radical compatriots just as quickly became respectable "good gays." It was but a logical progression when queer national activists gave way to queer-conformist consumers, and the corporate media began touting "metrosexuality."

\section{My Own Private Bear History Project}

During the mid-1980s something was percolating in gay San Francisco. The phenomenon of "bears" broke into my consciousness when I returned to the City in 1989, after spending a year on the East Coast in my first-ever professional position as a visiting lecturer at a small, smart, rural liberal arts college. ${ }^{7}$ It had been a thoroughly miserable year for me, away from anything and everything gay. I had envisioned it as a sabbatical year away from AIDS, a chance to escape the daily impact of living in the Gay Holocaust. In the end, it proved a terrifying experience-so far away from anyone who understood my epidemic-ravaged world-indeed, in a place where revealing my HIV status simply gave locals "legitimate" motivation to shun me. I obligingly made myself "invisible," retreating into the isolation of my trauma. Later, back in San Francisco, I sought to reengage with life, to take charge of living with HIV and (what would prove to be but the first attempt) to mourn the loss of vision of what my life was supposed to be (something, anything other than what it had become). I attempted to reinsert myself into life through companionship with my new-found bear friends, and I sought to wring for myself a new vision.

Doing bear history, then, began for me as a project of trauma resistance. When I began recording my observations about the phenomenon of bear sexual subculture in San Francisco in the 1980s, I sought to capture history as it was happening, and to prevent what

${ }^{7}$ I describe some of this experience, in terms of returning to my family home and dealing with clashes between my blue-collar sensibilities and the normative class values of an elite institution in Wright (1999). 
Milan Kundera calls "organized forgetting" (in Sturken 7). At the time, I did not grasp, nor could I have grasped, the complexity or the subtle difficulties involved - the impossible task of completely separating personal memory from collective memory, personal experience from collective experience, or how foreboding the task of extrapolating a consistent narrative that might pass muster as official historical record.

During the 1970s and 1980s, I matured intellectually in parallel to the practices of creating, discovering, and inventing GLBT history. Such practices have been developed in the face of ongoing historical erasure. In a mere twenty years, the bear subculture has exploded across the international queer scene, traversing at least three distinct generations of bears, so as to be radically transformed into both more complex variations and almost a caricature of what it began in opposition to. "The writing of a historical narrative," Sturken observes, "necessarily involves the elimination of certain elements" (8). I had a profound personal sense of having been "forgotten," over and over again myself, and I was not about to allow this new birth to which I was a witness be lost in the morass of the massive loss of collective memory caused by the AIDS epidemic. I am unabashedly still a GLFgeneration ${ }^{8}$ activist, for whom "gay" still connotes a radical/progressive, queerer than "queer" political concept and utopian vision. In the moment of their emergence, bears in the San Francisco queer culture were a first and last instance of this gay utopia.

\section{What Is a Bear?}

Setting aside the problematic of whether to speak of a bear "community," "cult," "subculture," or "movement," much of the vitality of the bear phenomenon arises from its undefinability. Simply put, a bear is a gay male who has tended to self-define by two distinct categorical aspects: (1) a preponderance of male secondary sexual

${ }^{8}$ The Gay Liberation Front was organized out of the spontaneous Stonewall riots in New York City in 1969, and emerged as a radical political force, giving voice to a gay sexual-liberationist vision that aligned sexual outsiders with the resistance politics of the era-women's liberation, black pride, the anti-war (in Vietnam), and others. While "gay" included homosexual men and women, it was implicitly pan-sexual in theory. Within ten years, "gay" had elided into "white, middle-class, urban male," "assimilationist," and "AIDS-infected," none of which had been anticipated, nor could have been foreseen in the earliest days. 
characteristics (beard, body hair, and girth, especially as it is typically distributed across the male torso) and/or (2) an essence of mind, spirit, personality, or sexual-politics that sets the self-identifying bear apart from normativizing contemporary gay mainstream values. In 1997, when The Bear Book: Readings in the History and Evolution of a Gay Male Subculture was published, I was able to summarize a decade of bear community internal contestation thus:

it is impossible to answer the question "What is a bear?" in any definite way, beyond the array of connotative associations in our culture, suggesting a large or husky body, heavy body hair, a lumbering gait, an Epicurean appetite, an attitude of imperturbability, a contented self-acceptance of his own masculinity (however that may be defined). The debate, generally framed as bear-as-image versus bear-asattitude, is as unresolved as ever. (21-22)

Five years later (in 2002), Ron Suresha iterated the same paradigm shift in masculinity that I had observed in The Bear Book (1997) and The Bear Book II (2001), and observes further that bears are more than "rejection of the rejecters." In Bears on Bears he points to a deepening of the mythic turn, a connection between selfidentifying bears and non-bears alike. He reads this connection as speaking to

our need to connect with the natural world, to the lost ancient myths, to the rhythms of the sacrificial hunt and the renewal of hibernation, to the protective nurturing of the Bear (Earth)

Mother, and the heroic activity of the Bear-son warrior. (xvii) The self-contradictions of bear identity grow only more glaring with the passage of time. The more categorically defining the predominantly North American, white, middle-class male homosexual bearas-image appears to become, the more the creative, thoughtful, visionary, non-North American, non-English-speaking, nonhegemonic visions and practices of the former bear-as-attitude have become remarginalized. The collective historical memory has undergone a profound forgetting and revision, not unlike the fate of Harry Hay ${ }^{9}$ and the early Mattachine Society.

${ }^{9}$ See Stuart Timmons' biography The Trouble with Harry Hay: Founder of the Modern Gay Movement (1990) or Hay in his own words in Radically Gay: Gay Liberation in the Words of Its Founder (1996), edited by pioneering gender anthropologist Will Roscoe. 


\section{Bears as Sexual Refugee Camp}

In the first moment of bear-identity formation in the early to mid1980s, at least in San Francisco, self-identifying bears found likeminded companions through a localized social-sexual nexus. The daily street carnival that Castro Street had become during the 1970 s had disappeared virtually overnight. In its stead, a scared, traumatized, predominantly gay male population saw a whole world disintegrate ("lifestyle" blithely leaves out the material, emotional, and intellectual agencies of community and social adhesion). Fear of the unknown concretely meant fear of infection and death, causing the sexual subculture to shut down almost completely. Gay bars, clubs, and business owners died rapidly. People stopped going out, businesses plummeted. The bathhouses were closed. In short, the gay boom town went bust, and most gay men feared gay community itself would disappear permanently.

It is vital to understand, from today's perspective, how overwhelming and total was this moment, when it looked like the gay world had reached cataclysmic annihilation. It was into this world that some gay men found, or rather invented, reinvented, themselves as (self-identifying) bears, as a strategy to cope with and move past the historical moment of trauma. It was a time for feeling one's way out of the metaphorical darkness, back into community, back into sexual connection and social adhesion. It was an opportunity to jettison the baggage of failed past experiments.

Several years later, when I suddenly and unexpectedly found myself on a figurative ledge, out of and far away from the maelstrom, I felt moved, inspired, grateful in the way that trauma survivors often are, to have survived. I wanted to do something to honor the experience that I and others had survived and to create a worthy meaning from the ruins. As someone who had long lived the political axioms "the personal is political" and "the private is public," I sought to realize the experiment to create an archive and document a history that was both intensely personal and quintessentially communalmy own private urban queer bohemia.

Since founding the Bear History Project (BHP) ${ }^{10}$ I have pursued both a path of collating, documenting and preserving, as well as a

$10<$ URL: www.bearhistory.com>. 
path of actively creating, bear culture. Until now I have sought rigorously to function simultaneously on both levels - to retain my own private sense of bearness, while being open to any and all fellow bears, energetically seeking out as many different voices as possible. I imagined it would be left to future generations to cull out what they would find to be, or wish to have be, representative of their bear history. I now seek to articulate private contexts and visions which have also shaped this enterprise, to explore, with guidance and insight from Ann Cvetkovich, in her An Archive of Feelings, the (albeit highly subjective) confluence of personal and collective trauma and the public historical aspects of bear culture.

For me beardom was about gay liberation, all over again. When I had been living, learning, and practicing emancipation politics in Germany during the 1970s, I digested the unfolding social movement in the United States. Radical European politics were informed by the politics and theories of the spirit of May '68, which meant that my incipient radical politics were as well. The Marxist-oriented leftwing of German gay emancipatory politics was deeply informed by both the French intellectual spirit as by American-style GLF, as imported by film-maker and gay activist Rosa von Praunheim. ${ }^{11}$

My first place of centering, one which exists nowhere in the real world but rather suspended in my consciousness, between gay radical German politics and an American Gay Liberation Front utopian vision, occurred when I read Carl Wittman's "Refugees from Amerika: A Gay Manifesto" (reprinted in McCaffrey). Immediately, I translated it into German and brought it to our local iht [Initiativgruppe Homosexualität Tübingen] for discussion.

In the 1960s, Wittmann had been a leader of the radical leftwing Students for a Democratic Society, who moved to San Francisco where he worked as a labor organizer and, as a result of his experience with leftist homophobia, came out. In 1970 he wrote his gay manifesto. He articulated a leftist critique of heterosexist society, arguing, "we know we are radical, in that we know that the system we're under now is a direct source of oppression, and it's not a

11 North American readers may find basic background information in Paul Berman's A Tale of Two Utopias, as well as the English translation of Rosa von Praunheim's Army of Lovers (1980), originally published as Armee der Liebenden oder Aufstand der Perversen (1979). 
question of getting our share of the pie. The pie is rotten."12 He urged gay people to come out as an act of personal and societal liberation, and he articulated a vision of San Francisco as a gay ghetto, a refugee camp to escape the oppression of America.

And so, in 1979, I fled Germany, and heteronormative society in toto, to seek community in Wittmann's refugee camp-San Francisco's Castro District. Little did I know nor could I have anticipated what a crass commercial endeavor it would be, nor how fixing up run-down and abandoned neighborhoods would escalate into an insatiable urban real estate redevelopment engine that, thirtyfive years later, has placed the cost of urban living out of the hands of all but the wealthiest minority. Nor did I anticipate the increasingly conservative thrust to political conformity, which, by the time I had reached the shores of San Francisco, had transformed into assimilationist political conformity and the socio-sexual conformity of the Castro Street clone. Coincidentally, I was manifestly at the Castro clone demographic dead center-26, 5'9", 29-inch waist, wearing 501 jeans and flannel shirts. But, on the inside, I could not have been more alien. Where was the sexual democracy I had expected: men and women of whatever non-conformist bent, coming in every shade, shape, color, and persuasion, united only in our radical vision of community? Like many an immigrant before me, I was bewildered and dumbfounded to find myself more of an alien-a sexual alien - than ever before. I had come home, and my house (like Odysseus's) was filled with strangers. And, as I was about to rudely discover, I was plummeting to the depths of full-blown alcoholism and drug addiction. All the neat gay urban homesteads and, by turns funky, campy, or chic gay businesses looked very peculiar from my vantage point as an unanticipated 26-year-old gutter drunk.

$* \quad * \quad *$

12 Quoted in "Don't Worry, Honey, Your Roots Aren't Showing" by Karen J. Hall. Wittman's "Refugees from Amerika: A Gay Manifesto" was originally printed in 1970, reprinted in the gay underground press across the US in 1971, and reprinted in The Homosexual Dialectic (1972). I was in correspondence with Wittman when he was living at the Wolf Creek commune in Oregon editing RFD magazine, and I was an activist in Tübingen. He later moved to North Carolina, and succumbed to AIDS in 1986. 


\section{8 / Wright}

Arthur Frank notes that the wounded storyteller has been in our cultural memory since ancient times, pointing to the ancient Greek Tiresias, as well as the Biblical figures of Job and Jacob. Each of them experienced anguishing wounding, from which they derived their power to speak the truth and to be heard. Frank focuses on the truth stories that ill people can tell, and how the "ill person who turns illness into story transforms fate into experience" (xi-xiii), thereby transforming the sick person as passive victim of illness into the active shaper of one's own healing. Frank identifies three types of narratives that the wounded storyteller may relate: the restitution narrative (illness as a temporary setback on the path back to health), the chaos narrative (illness or wounding that engulfs and has no end), and the quest narrative (whereby illness becomes the disabling contingency that leads to insight and "control of a higher level") (Frank 126). Quest narratives are very popular, and are the ones most frequently written down and published, in collections of memoirs, manifestos, and other personal testimonies.

A central component of the recovery process in Alcoholics Anonymous and other twelve-step programs is a daily recounting of "recovery stories." Each person who finds his or her way into the rooms of AA is obligated to construct a narrative of a three-phase path to recovery. It includes a "before" ("bottoming out"), a transformative "moment of clarity" ("came to see"), and an "after" (the path to sobriety), the hopefully uninterrupted and continuing narrative of life in sobriety. Recovery is contingent upon embracing a new social identity: "being sick," suffering from the disease of alcoholism.

A fundamental recovery strategy of the "drunk-alogue" is to give the newly "ill" individual a means to extract himself from a chaos narrative (of being unable to control one's drinking) with a quest narrative (getting sober was about discovering a whole new way of conceiving of living), which is framed as a restorative narrative ("being restored to sanity," in the language of AA). Though no one is ever "cured," as one progresses, heals, or gets better in sobriety, one's personal narrative changes. The drunk-alogue is flexible and one is encouraged to continually re-evaluate one's understanding of the past in light of new insight. The person in recovery modifies his or her drunk-alogue, to recast personal history, so as to reflect newer insight and better understanding. 
I have long thought of gay coming-out stories along similar lines. Life before and after the moment of intimation, of accepting a truth about oneself as a gay person, has made much sense to me when thought of this way. The after portion, to my sensibility as a Stonewall/GLF-era gay man, automatically includes a growing political conviction, by which one is compelled to become an advocate for social change. (Of course, this is the same model of narrative whereby right-wing Christians are also "reborn": see Mellon.) While I first became conscious of the healing strategy of the recovery narrative through AA, I have become even more struck by its structure at the heart of gay coming-out strategies. Having come out alive, as gay, and, later, as sober, it seemed natural to come out as a PWA, and, later still, as a bear. In the 1980s, bears were typically gay men who came out twice-the first time as gay, the second as a bear. Today, the concept of bear has become fundamental, and younger teenaged males may come out as a bear (wherein bear replaces gay as the basic identity category). Others may come out as a bear, after coming out in some other way, and then negotiate the category of bear as "not only male gay," for example, as a bear of color, or as a transgendered, bisexual or lesbian bear.

I originally debuted as a "sober leather bear." What makes my story different from most bears', whether in the 1980s or today, is twofold. First, I got sober before bears happened, so being a bear was anteceded by sobriety-I could become a bear because it could be a sober identity for me. Secondly, I was conscious of being HIVinfected (indeed, I had fully expected to have died from AIDS) before bears ever came into being; I could become a bear as a gay man with HIV. What for me has been so disorienting and demoralizing has been the evolution of bears, along the hippie-yuppie fault line, into a category whereby being sober and having HIV are now qualities that separate me from, rather than bond me with, other self-identifying bears. Now, I am a bear with a difference, a queerly queer bear-I am a trauma bear. I live, and I have lived for many years now, with the double sense of time of the trauma survivor, even exponentially doubled vision. I am always in the moment of the trauma and in the present moment. On one level, time is forever frozen; on another it hurdles unstoppably forward. I have changed identities and traveled under new, sometimes false, passports several times in my life. After 
all, is not the United States the society where everyone is not only free, but frequently exhorted to "reinvent yourself"? ${ }^{13}$

\section{Archiving Fluid Cultural Spaces}

As research librarian and leathersex historian Rob Ridinger highlights, in his "Things Visible and Invisible: The Leather Archives and Museum," much if not most of the reclamation project of defining, recording, documenting, and archiving gay and lesbian history has focused on "significant individuals, organizations and communities, with the collection and preservation of such materials early recognized as a priority by gay and lesbian information professionals" (2). Ridinger points out that such collecting has drawn upon materials "easily recognized" as a priority, such as community newsletters, newspapers, histories extrapolated from public documents and other written records (as epitomized by Jonathan Katz's ground-breaking Gay American History), and oral histories taken from recognized leaders and other noted individuals representative of the visible segment of the gay and lesbian community.

Ridinger both explains and justifies the need for a separate leather/levi and S/M ("leathersex") museum and archiving program. Even as gay and lesbian historians, anthropologists, and other social scientists laid the groundwork for modern gay and lesbian historiography, including documenting then-current gay and lesbian history in the latter third of the twentieth century, the already extant leathersex community was frequently overlooked by the newly-

${ }^{13}$ For example, recall Michael Valentine Smith, in Robert Heinlein's science fiction cult classic Stranger in a Strange Land, which explains that on Mars, when a place became too filled with experiences, the inhabitants simply picked up and moved on, and settled in a fresh, new place, free of past experience. I read and reread this book several times as a young teenager. I am thinking too of Steven Spielberg's film Artificial Intelligence, in which a similar sense of double vision is related, specifically in terms of a child abuse survivor. As a recreation of the tangled memories and desire of the trauma victim, the film logically ends with the mecha (robot) boy-as-Pinocchio at the feet of the Blue Fairy, eternally desiring to be reunited with his "mother." Spielberg adds a Hollywood happy ending, whereby the Blue Fairy grants the mecha boy "a perfect day" with his mother. This ending infuriated many abuse survivors in the audience, but reveals the publicly-sanctioned, permissible discourse, which requires such pain and loss be stricken from the record. It is precisely this life-destroying sanction Audre Lorde wrote in defiance of. My essay is both a documentation of and part of the actual process through which $I$ have been learning how to transcend the impossible double vision-certainly not through the simplistic wish-fulfillment of Heinlein's Martian. 
emergent "gay-mainstream" historians. Interestingly, even as "gay and lesbian" was expanded to "GLBT" or "queer" (and the terms may be understood as complementary or identical with each other, depending on the historical or theoretical perspective), to recognize and call for "minority" or "cultural diversity" histories (notably African-American, Latino/a, Asian-American, and others), the leather/levi and $\mathrm{S} / \mathrm{M}$, or learthersex, or radical sex communities remained marginal to the national project.

The leather community, which has its roots in immediate postWorld War II American society, developed independently of the institution of the gay bar, the primary gay "safe" space prior to Stonewall-era activism. The leather community spaces were more typically temporary, ad hoc spaces, such as motorcycle-run sites and campgrounds, and privately owned facilities, all of which helped to keep leather spaces less vulnerable to harassment. While leather bars have existed since the post-war years, the ad hoc spaces and private facilities often remain primary leather community spaces to this day.

While gay activism became increasingly articulated and organized around altering public, legal, and medical boundaries to include (or assimilate) gay men and lesbians into mainstream society, the leather community offered "clear and simple definitions of identity, setting forth acceptable standards of behavior and guidelines" for social relations that "emphasized the recognition, valuing, and respecting of seniority and experience" (Ridinger 4). In short, the leather community has traditionally been inward- and initiation-focused, and has traditionally expended much energy on developing a tight-knit social group, all of which are hallmarks of minority communities that seek to peacefully coexist with a larger dominant society. The analogies - to Jewish, African-American, Chinese-American, and other minority cultural structures-make transparent the American-ness of these social negotiations, as well as their cultural-minority status. At present, the leather community remains proudly, even fiercely, independent, while individual leatherfolk and leather community organizations are deeply intertwined in GLBT community at every level.

On the contrary, bear, as a gay, bi, trans, lesbian or queer identity, remains virtually unknown in American mainstream society. It is curious that even at the time of this writing, some twenty years after the emergence of self-identifying bears within the GLBT, queer, and 


\section{2 / Wright}

leather communities, bears remain essentially invisible at the level of public discourse or cultural-political recognition. Bears, it seems, are rarely mentioned, and, if they are, the remark often contains some sense of incomprehension or bemusement (the oddness of a bear identity), or some form of social disapproval (fat, hairy, older, ugly gay men "doing" bear "drag"). Bears remain on the margins of gaymainstream society (as they represent the undesirable "real" in the face of "ideal" gay male beauty), even as they continue to assimilate to the standard bearer of a new normative "straight gay."

That said, by 2005 (at the time of the publication of this article), no one, it seems, can remember a time before there were bears. Bear social organizing followed structural development similar to the leather community's - a separate, parallel subculture, of fluid, temporary, ad hoc spaces, including early innovative use of cyberspaces - and have continued to hold a similar cultural-minority status, on the margins of gay-mainstream community and with a notunproblematic relationship to the leather community. At some times and in some places, bear and leather communities overlap profoundly. Elsewhere, bear and leather are self-defined antitheses to each other, both marginal to the mainstream, and at times, either or both may vie for and assert status as a core element in a local gay-mainstream community arrangement.

As Ridinger notes at the outset of his account, a fundamental problem in gay and lesbian history preservation work is "that a subject must be recognizable and capable of definition before the basic parameters of research can be set" (2). An obvious challenge for me in attempting to take snapshots (in Foucault's sense of cultural history as archaeology) of bears-in-formation has been having to create some arbitrary working parameters. Designated "bear spaces" (such as private social and sexual spaces, cyberspaces, bear bars or bear nights at local leather bars) helped-or, perhaps, forcedindividuals to identify as bears or to at least develop a working definition for the identity.

I have always explicitly employed the term "self-identifying bear." Experiencing the rise of a bear identity makes it impossible not to be aware of the construction of social identities. Anyone within or aware of gay history is also acutely aware of the politics of identity labeling: one is hyperaware of never knowing whether to use "gay" or "GLBT" or "queer," or is struck by the intense American-ness of 
the sensitive preoccupation of cultural-minority identity labeling. Indeed, if anything, "bear" strikes me as a last wave in sexuality-asethnicity identity politics. Self-identifying leaves open space for the individual bear to negotiate his (or her) parameters of "bear."

Bear identify has been divided by two opposing tendencies-are bears about fetishizing secondary male sexual characteristics or are bears about redefining what it means to be a (gay) man, i.e., bears as "laid-back," "gregarious," "nurturing" or relatively "attitude-free"? Embedded within this simple bipolar opposition (as it is thought of and popularly applied) we find another cultural-political dynamic. The former stance brings us both into realms of leather community concerns (sexual fetish as a component of social identity and practice), and gender and sex politics (the relationship between biological and cultural definitions of male gender). In the latter side of the polarity, we find an even more complicated blurring of how we distinguish between male (biological), masculine (qualities ascribed to men's appearance and behavior), and previously unnoticed differences between heteromasculine normativity and its queer (such as the "straight gayness" of clones ${ }^{14}$ ) variations. In either case, being a bear has everything to do with rethinking or revisioning "masculinity."

In this sense, "bear" shares much in common with "leather." The leather community has consciously and actively explored and reset the boundaries for defining, among other things, "masculinity" within its culture. The nascent bear community has done so as well. Bears fetishize facial and body hair, but in a different way from the leather community, and clearly in a different way from gaymainstream community, where a clean-shaven face even full-body depilation, is at present a base line standard for measuring sexual desirability. To have a fat or obviously untamed or unregulated body is be a "failure" as a gay man. The physicality of "bear" has also challenged the (often media-driven) gay-mainstream value of bodyas-commodity, whereby not just sexual desirability but social recognition per se is contingent upon conformity to a "fit body" standard. Self-identifying bears have claimed the non-conforming masculine or male body as the primary physical site of their implicit cultural sex and gender politics. The assertion of bearish bodies arose

${ }^{14}$ See Martin P. Levine's Gay Macho: The Life and Death of the Homosexual Clone. 


\section{4 / Wright}

as conscious refutation of "clone" and "twink" models of beauty, and occasionally of "good gay" or "consumer queer" values and fashions (urban, white, upwardly-mobile middle-class).

However, as the notion of bears has permeated queer culture and media and reached a greater level of acceptance, bears have increasingly acculturated to gay-mainstream values. "Musclebears," "A-list bears," and those more formally recognized as "superior" through celebrity (bear contest winners, magazine cover models, objects of flattering gossip in electronic and print media) signal the transformation of the bear phenomenon into a structured and self-regulating community assimilating into the gay-dominant value paradigm. However, in the millenial decade, the fad of "metrosexuality" made plain the problem of social "acceptance" of gay men by mainstream society. Everything positive (and stereotypically) gay becomes viewed as a taste, a sensibility, a mannerism, to be embraced and adopted by straight people. Metrosexual men dress, talk, comport themselves, and in general create the illusion of "being gay"-everything except expressing homoertoic desire. Bears may be seen as the exact obverse - reasserting sexual desire as primary to sexual identity.

During its first ten years and the second decade of bears (19942003), the Bear History Project itself underwent dramatic transformation. As the size and nature of bear community archiving became far more than a single person, with volunteers in the field, could handle; as technological changes (rise of the Internet and web-based communication) rendered the original methods of data-gathering antiquated; as the underlying cultural and political and historical concerns took clearer shape; and, as the project of the Bear Books necessitated an additional intervention of visual collecting and analysis-it became clear the BHP would need to reinvent itself (or rather, that I would need to rethink the BHP). The next steps included establishing a permanent repository at Cornell University's Human Sexuality Collection ${ }^{15}$ for the BHP, the creation of the Nashoba Institute, which serves as an umbrella for several related but free-standing components, and the formalizing of Nashoba as non-profit organization, ${ }^{16}$ which makes it a legitimate body capable of applying for and receiving grant monies and other institutional support for its work.

${ }^{15}$ Further information available at $<$ http://rmc.library.cornell.edu/HSC $>$.

${ }^{16}$ The Nashoba institute became a 501c3 non-profit organization in 2003. 


\section{Bear Archives of Trauma}

Thus far, I have attempted to untangle and demarcate some of the personal and private traumas which have both drawn me to the margins of society and to marginal cultures. I have passed lightly over traumas related to the effects of homophobia (and erotophobia) on gay and queer men, in favour of focusing on traumas of AIDS upon gay and queer community, arguing that bears were born, in part (and only in part), into this historic scene of AIDS trauma as a consequence and response. What motivated much of the early bearidentity social formation may be ascribed to coping with symptoms of trauma; at least this was the case for myself and the bears to whom I was most strongly drawn to psychologically, emotionally, spiritually, sexually.

Sharing Ridinger's observations about the "suppressed and traumatic histories" of marginalized sexual communities and their archives constructed from "ephemeral and unusual traces," Cvetkovich affirms that "in the absence of institutionalized documentation or in opposition to official histories, memory becomes a valuable historical resource, and ephemeral and personal collections of objects stand alongside the documents of the dominant culture in order to offer alternative modes of knowledge" (8). While, as I have mentioned, there is significant overlap between leather and bear communities, beyond HIV/AIDS, much of the unarticulated trauma that draws at least some bears into bear community is very different from that of the leather fraternity. While the leather community has often been stigmatized by the gay mainstream because of the social opprobrium placed on many forms of sexual fetishes embraced and celebrated by the leathersex community, the stigmatizing, and therefore traumatizing, difference for bears can be summed up in one word: "fat."

Bears wrestle with the problems of being a man (we lack meaningful analysis of the significance of gay male masculinitythe "man" part of gay man). Bears wrestle with the problems of being fat, of being "damaged goods" in a culture of complete selfcommodification. And, perhaps most of all, bears, wrestle with a unique conundrum, hinged as they are (to borrow from Cvetkovich) "between systemic structures of exploitation and opposition and the felt experience of them" (12). What still awaits a systematic analysis is the phenomenon and trauma induced by gay-on-gay homophobia. Fat gay men suffer the same sort of discrimination that (straight) fat 
women do. In a sexual subculture where looks are even more important than in mainstream society (because so much of it is about having sex), being sexually rejected-actively or passively, by being rendered invisible - constitutes a double trauma. Not only is one's choice of sexual partners greatly reduced, but one's entire raison d'être is rejected. In a society that has categorically defined homosexual men as "failures" as men, there can be no greater failure than to enter the gay world, only to find oneself being rejected as a "failed" homosexual (i.e., sexually desirable, sexually realized) man. In this context, Cvetkovich's insight is particularly underscored: “[i]n its unorthodox archives, trauma resembles gay and lesbian cultures, which have had to struggle to preserve their histories" (8).

\section{From Bears to Non-Hegemonic Masculinities}

The Bear History Project had originally been dedicated to traditional archival work-collecting bear-related publications, magazines, newsletters - as well as collecting and recording oral histories. The BHP has also gathered clipping files on bear-related topics, such as beards, body hair, bears as totemic symbols, bear celebrities from mass media and pornographic gay media. The approach chosen was the classic bottom-up perspective, both because I was a participant observer at the time and because that perspective seemed to embrace the very spirit of bearish enterprise. ${ }^{17}$ In the 1990 s, the second wave of bears brought massive community-building: bear-exclusive clubs, events, media, rules of dress and behaviors.

This accelerating process of transformation occurred faster than the BHP could keep up with. It became impossible to continue to gather and hold print documents, as, by and large, print-format club newsletters ceased being produced. There was a new crisis in how to document and preserve web sites and online newsletters. The sheer volume of online published material became overwhelming. ${ }^{18}$ The

${ }^{17}$ Much of this has been recorded in the two volumes I edited, The Bear Book (1997) and The Bear Book II (2001).

${ }^{18}$ Perhaps the most comprehensive web source for bear culture may be found at wwww.resourcesforbears.org, administrated by Bob Donahue. Fragments of the original Bear History Project may be accessed at www:bearhistory.com. One of the earliest bear clubs to organize and that is still in existence is the Bear Buddies of Toronto, at www.bearbuddiestoronto.com. More than a dozen bear-identified clubs were active across Canada at the time this article was completed. Although all links 
nature, function, and activities of the multitude of bear clubs posed another problem. And, the consolidation of a normalized, or gaymainstream-assimilated, bear value system radically transformed the public face of the bear community. It also profoundly altered the very nature of "beardom." The emergence of a bear celebrity hierarchy completed the transformation of bears-not just into an insider community within the gay-mainstream culture, but also a painful two-class social order. For some bears to be insiders, others msut be outsiders.

As the bear community has radically grown and transformed, and moved in many new directions, the BHP has had to be rethought and redeveloped. Much of the baseline archiving work now needs to be done on-site throughout the bear community, by individual bear clubs and other grassroots groups. The work of the Nashoba Institute is a discussion for another time and place. For our purposes here, it is significant as it demonstrates a concrete instrument through which the bear archive-as-trauma project has worked its way to a logical conclusion. It demonstrates a way in which the chaos narrative of living bear history in the moment of making has led to the construction of new quest narratives.

\section{Provisional Conclusions}

A full two years has passed between the time I received a note of positive interest from editor Sharon Rosenberg ${ }^{19}$ to write something about bear history as queer memorialization, and completion of the final manuscript. The bear phenomenon continues to gain ground as a gay mainstream identity, and that identity continues to solidify as a predominantly white, middle-class, male homosexual (and to a lesser degree, bisexual) phenomenon. The gap between fantasy ideal bears (capital-B bears) and everyday "average-Joe" bears (small-b bears) more readily maps onto the gaps of gay mainstream society. The

for the very popular Ours Montréal Bears club appeared inactive at the time of publication, active Montreal and Quebec bear groups include the dinner club Le G.R.R.R.R. A OURS de Montréal (http://www.upbear.com) and the Generation X club (http://genxbears.org/montreal).

${ }^{19}$ I wish to express my deep gratitude to Sharon Rosenberg, who could have had no inkling what a profound, transformative effect her invitation to contribute an understanding of my work would have on me personally or professionally. 
experimenters, dreamers, and sex and gender innovators of bearderived or bear-identified sensibilities have also proliferated, primarily through the far-reaching and anonymous effects of the Internet.

To my surprise, shock, and dismay, I became painfully aware of how much I had attached myself, personal values and sense of identity, to bear identity. The shock and dismay arose as bears went, at least in the publicly visible segments, in directions I had no desire to go myself. This has proved an enriching experience in observing how communities and societies function and develop, and in this sense bears have gone the same way as every other subculture or community I can call to mind. Similarly, it has been a very instructive firsthand experience in understanding the limitations of identity politics.

As I have worked my way through to understanding my own guiding beliefs and principles, for example as a radical egalitarian, as a relatively privileged (because) white multiculturalist and (because) male feminist, as an internationalist (with very USAmerican feet of clay), as a victim-survivor, I have slowly, painfully, and with large servings of humble pie learned my own limitations. I have healed victim-survivor wounds at long last (child abuse, AIDS, social marginalization). I experienced illness, nervous collapse, and the loss of a career vision in these past two years-all sparked, in part, by the self-inventorying this article necessitated.

The bear history work-my bear history work-is done. It is now the work of many others, who have very different stories to tell. Queer as one, queer as many, symbolize reality and the work that activists and historians must do. My path is now not one of contestation, but one of acceptance. I am bear unique unto myself, as I am queer in a multicultural community. I am finding a rebirth of my political activism through spiritual activism. What is important are not my words, but my actions.

\section{Works Cited}

Berman, Paul. A Tale of Two Utopias. New York: Norton, 1996. Cvetkovich, Ann. An Archive of Feelings: Trauma, Sexuality, and Lesbian Public Cultures. Durham, NC: Duke UP, 2003.

Erikson, Kai. "Notes on Trauma and Community.” Ed. Cathy Caruth.

Trauma: Explorations in Memory. Baltimore: Johns Hopkins UP, 1995. 
Frank, Arthur W. The Wounded Storyteller: Body, Illness, and Ethics. Chicago: U Chicago, 1995.

Frankl, Viktor E. Man's Search for Meaning. New York: Washington Square, 1985.

Hall, Karen J. "Don't Worry, Honey, Your Roots Aren't Showing." Syracuse Peace Council Newsletter 710 (2002). 26 September $2004<$ http://www.peacecouncil.net/pnl/02/710/710GLBT Pride.htm>.

Heinlein, Robert A. Stranger in a Strange Land. New York: Putnam, 1961.

Herman, Judith Lewis. Trauma and Recovery. New York: Basic, 1992.

Higgs, David, ed. Queer Sites: Gay Urban Histories Since 1600. New York: Routledge, 1999.

Levine, Martin P. Gay Macho: The Life and Death of the Homosexual Clone. New York: New York UP, 1998.

Lorde, Audre. Zami: A New Spelling of My Name. Freedom, CA: Crossing, 1982.

McCaffrey, Joseph A., ed. The Homosexual Dialectic. Englewood Cliffs, NJ: Prentice-Hall, 1972.

Mellon, John C. Mark as Recovery Story: Alcoholism and the Rhetoric of Gospel Mystery. Urbana, IL: U Illinois P, 1995.

Mogenson, Greg. God is a Trauma: Vicarious Religion and SoulMaking. Dallas: Spring, 1989.

Nelson, Emmanuel S., ed. AIDS: The Literary Response. New York: Twayne, 1992.

Praunheim, Rosa von. Armee der Liebenden oder Aufstand der Perversen. Munich: Trikont, 1979. [Translation: Army of Lovers. London: Gay Men's Press, 1980.]

Preston, John, ed. Hometowns: Gay Men Write About Where They Belong. New York: Dutton, 1991.

Ridinger, Robert B. Marks. "Things Visible and Invisible: The Leather Archives and Museum." Journal of Homosexuality 43.1 (2002): 1-9.

Roscoe, Will, ed. Radically Gay: Gay Liberation In the Words of Its Founder Harry Hay. Boston: Beacon, 1996.

Salih, Sara, ed., with Judith Butler. The Judith Butler Reader. Malden, MA: Blackwell, 2004. 
Sontag, Susan. Illness as Metaphor and AIDS and Its Metaphors. New York: Anchor, 1990.

Sturken, Marita. Tangled Memories: The Vietnam War, the AIDS Epidemic, and the Politics of Remembering. Berkeley: $\mathrm{U}$ California P, 1997.

Suresha, Ron Jackson. Bears on Bears: Interviews and Discussions. Los Angeles: Alyson, 2002.

Timmons, Stuart. The Trouble with Harry Hay: Founder of the Modern Gay Movement. Boston: Alyson, 1990.

Wright, Les. "San Francisco." Queer Sites: Gay Urban Histories Since 1600. Ed. David Higgs. New York: Routledge, 1999. 164 89.

Wright, Les. "Clinton, NY." Hometowns: Gay Men Write about Where They Belong. Ed John Preston. New York: Dutton, 1991. 137-51.

—. "Gay Genocide as Literary Trope." AIDS: The Literary Response. Ed. Emmanuel S. Nelson. New York: Twain, 1992. $50-68$.

ed. The Bear Book II: Further Readings in the History and Evolution of a Gay Male Subculture. New York: Harrington Park, 2001.

- ed. The Bear Book: Readings in the History and Evolution of a Gay Male Subculture. New York: Harrington Park, 1997. Young, Allan. "Suffering and the Origins of Traumatic Memory." Daedalus 125.1 (1996): 245-60. 